University of Nebraska - Lincoln

DigitalCommons@University of Nebraska - Lincoln

Publications from USDA-ARS / UNL Faculty

U.S. Department of Agriculture: Agricultural

Research Service, Lincoln, Nebraska

1980

\title{
Androgen response of cryptorchid and intact rams to ovine LH
}

B. D. Schanbacher

USDA-ARS

Follow this and additional works at: https://digitalcommons.unl.edu/usdaarsfacpub

Part of the Agricultural Science Commons

Schanbacher, B. D., "Androgen response of cryptorchid and intact rams to ovine LH" (1980). Publications from USDA-ARS / UNL Faculty. 780.

https://digitalcommons.unl.edu/usdaarsfacpub/780

This Article is brought to you for free and open access by the U.S. Department of Agriculture: Agricultural Research Service, Lincoln, Nebraska at DigitalCommons@University of Nebraska - Lincoln. It has been accepted for inclusion in Publications from USDA-ARS / UNL Faculty by an authorized administrator of DigitalCommons@University of Nebraska - Lincoln. 


\title{
Androgen response of cryptorchid and intact rams to ovine LH
}

\author{
B. D. Schanbacher \\ Roman L. Hruska U.S. Meat Animal Research Center, Science and Education Administration- \\ Agricultural Research, U.S. Department of Agriculture, Clay Center, Nebraska 68933, U.S.A.
}

\begin{abstract}
Summary. Surgically induced cryptorchidism in rams resulted in elevated serum concentrations of $\mathrm{LH}$ but near-normal concentrations of androgen (testosterone and $5 \alpha$-DHT). Injections of ovine $\mathrm{LH}(2 \times 50 \mu \mathrm{g} ; 2 \times 500 \mu \mathrm{g})$ resulted in maximal androgen secretion in the intact rams and similar but lower concentrations in cryptorchid rams. Peak concentrations were 14.9 and $8.5 \mathrm{ng} / \mathrm{ml}$ in the intact and cryptorchid rams respectively $(P<0.05)$.
\end{abstract}

\section{Introduction}

The ability of the cryptorchid testis to secrete testosterone is thought to be impaired relative to that of the normal scrotal testis because serum levels of testosterone in cryptorchid rats are normal or below normal when serum levels of LH are significantly increased (Swerdloff, Walsh, Jacobs \& Odell, 1971; Rager, Zarzychi, Eichner \& Gupta, 1975; Gomes \& Jain, 1976; Sharpe, Kerr \& de Kretser, 1978). Similar findings have been reported for cryptorchid rams (Schanbacher \& Ford, 1977) and bulls (Schanbacher, 1978, 1979). Furthermore, the cryptorchid testis of the rat (Llaurado \& Dominquez, 1963), dog (Eik-Nes, 1966) and bull (Schanbacher, 1979) responds poorly to exogenous gonadotrophin. The present study was to determine the ability of the testes of the cryptorchid ram to secrete testosterone in response to LH.

\section{Materials and Methods}

The rams were of mixed breeding and were 2-3 years of age at the time of the study: 5 were sham-operated and left intact and 5 had been surgically made cryptorchid at 6 weeks of age. The rams were transferred from pasture to a small holding area and indwelling jugular catheters were inserted. After acquaintance with the 2 individuals taking the blood samples, each ram received 4 intravenous injections of purified LH (NIH-LH-S18). The protocol was similar to that described by Amann, Nett \& Niswender (1978) in that $50 \mu \mathrm{g} \mathrm{LH}$ were given at 10:00 and 10:30 h and $500 \mu \mathrm{g} \mathrm{LH}$ were given at 11:00 and 11:30 $\mathrm{h}$. Blood samples $(\sim 4 \mathrm{ml}$ each) were collected at 20min intervals starting at $08: 20 \mathrm{~h}$ and ending at 15:00 h. The samples were allowed to clot, and then centrifuged at $1500 \mathrm{~g}$ for $30 \mathrm{~min}\left(4^{\circ} \mathrm{C}\right)$. The serum was frozen at $-20^{\circ} \mathrm{C}$ until assayed for concentrations of $\mathrm{LH}$ and testosterone.

LH was determined by the double-antibody radioimmunoassay procedure described by Schanbacher \& Ford (1976). All samples were assayed in duplicate within a single assay and NIH-LH-S 18 was used as the reference standard. The intra-assay coefficient of variation was $<10 \%$ for each duplicate and assay sensitivity was $0.5 \mathrm{ng} / \mathrm{ml}$.

$0022-4251 / 80 / 030151-04 \$ 02.00 / 0$

(C) 1980 Journals of Reproduction \& Fertility Ltd

This article is a U.S. government work, and is not subject to copyright in the United States. 
Testosterone was determined by radioimmunoassay after ether extraction (Schanbacher, 1976). Samples were assayed in duplicate, and chromatography was omitted. The testosterone antiserum cross-reacts with $5 \alpha$-dihydrotestosterone approximately $70 \%$; therefore, assay values reflect concentrations of both androgens. The intra-assay coefficient of variation was $<12 \%$ for each duplicate and assay sensitivity was $0.2 \mathrm{ng} / \mathrm{ml}$.

Differences in specified means were tested statistically by Student's $t$ test.

\section{Results}

The results are shown in Text-fig. 1. Before injection, serum $\mathrm{LH}$ ranged from 1.3 to $1.6 \mathrm{ng} / \mathrm{ml}$ in intact rams and 4.3 to $6.5 \mathrm{ng} / \mathrm{ml}$ in cryptorchid rams. Although LH was consistently elevated $(P<0.01)$ in cryptorchid rams, serum androgen concentrations were similar $(P>0 \cdot 10)$. Androgen decreased from 6.4 to $2.0 \mathrm{ng} / \mathrm{ml}$ for no apparent reason during the period before $\mathrm{LH}$ injection in intact rams and fluctuated between 3.3 and $4.4 \mathrm{ng} / \mathrm{ml}$ in cryptorchid rams.
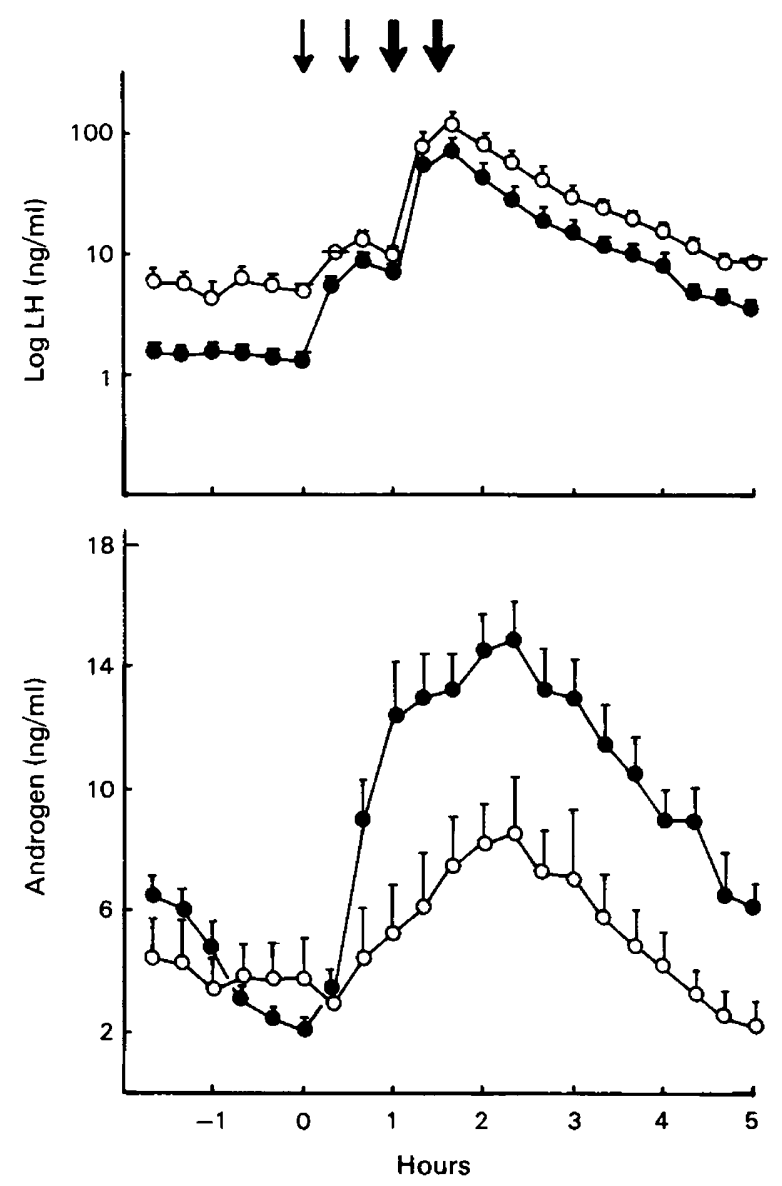

Text-fig. 1. Serum concentrations of $L H$ and androgen in intact $(\bullet)$ and cryptorchid $(O)$ rams injected with $50 \mu \mathrm{g}$ ovine LH (small arrows) and $500 \mu \mathrm{g}$ ovine LH (large arrows). Each point represents the mean \pm s.e.m. for 5 animals. 
Serum LH concentrations increased markedly after the first $2 \mathrm{LH}$ injections and still further after the next 2 injections. Maximum concentrations (intact rams: $62.9 \pm 13.8 \mathrm{ng} / \mathrm{ml}$; cryptorchid rams: $115.0 \pm 19.5 \mathrm{ng} / \mathrm{ml}$ ) were observed immediately after the last injection.

Androgen response by the intact rams to injected $\mathrm{LH}$ was more rapid and of greater magnitude. Serum values were significantly elevated $(P<0.01) 40 \mathrm{~min}$ after LH injection in intact rams, but the peak concentration at $140 \mathrm{~min}(14.9 \pm 1.4 \mathrm{ng} / \mathrm{ml})$ was not significantly greater than that at $60 \mathrm{~min}$. In the cryptorchid rams the peak concentration at $140 \mathrm{~min}$ $(8.5 \pm 1.9 \mathrm{ng} / \mathrm{ml})$ was significantly lower $(P<0.05)$ than that in the intact rams.

\section{Discussion}

Maintenance of normal serum androgen concentrations in cryptorchid rams appears to be dependent on elevated concentrations of serum LH. Previous investigators have reported elevated LH for natural and surgically induced cryptorchid rams (Hillard \& Bindon, 1975; Schanbacher \& Ford, 1977). Results from this study and those published previously (Schanbacher \& Ford, 1977) show that the cryptorchid ram testis responds to gonadotrophic stimulation, but maintains normal serum testosterone inefficiently.

The androgen response to two 50- $\mu \mathrm{g}$ injections of $\mathrm{LH}$ appears near maximal because the incremental increase in serum androgen was not appreciably changed when intact rams were treated with two additional $500-\mu \mathrm{g}$ injections of LH. Response of the cryptorchid ram to LH was significantly reduced at all time intervals studied, even though the secretory profile was parallel to that of intact rams. This suggests an effect of cryptorchidism on the interstitial cells involved in androgen production as well as the germinal components of the testes.

The cryptorchid bull maintains near-normal serum testosterone concentrations but fails to respond to exogenous gonadotrophin (Schanbacher, 1979). The consequences of cryptorchidism have been most extensively studied in the rat (Kerr, Rich \& de Kretser, 1979; Schanbacher, 1980), but the specific lesion, whether primary or secondary to the Leydig cell, has not been identified. Evidence from several species shows that cryptorchidism alters Leydig cell function and upsets the normal pituitary-testicular endocrine axis.

The technical assistance of Ms Becky Chmelka and Ms Marilyn Bierman and the cooperation of the Nebraska Agricultural Experiment Station, University of Nebraska, Lincoln, are gratefully acknowledged.

\section{References}

Amann, R.P., Nett, T.M. \& Niswender, G.D. (1978) Effects of LH, FSH, prolactin and $\mathrm{PGF}_{2} \alpha$ on testicular blood flow and testosterone secretion in the ram. J. Anim. Sci. 47, 1307-1313.

Eik-Nes, K.B. (1966) Secretion of testosterone by the eutopic and the cryptorchid testis in the same dog. Can.J. Physiol. 44, 629-633.

Gomes, W.R. \& Jain, S.K. (1976) Effect of unilateral and bilateral castration and cryptorchidism on serum gonadotrophins in the rat. J. Endocr. 68, 191-196.

Hillard, M.A. \& Bindon, B.M. (1975) Plasma LH patterns in cryptorchid rams and wethers. J. Reprod. Fert. 43, 379-380.

Kerr. J.B., Rich, K.A. \& de Kretser, D.M. (1979) Alterations of the fine structure and androgen secretion of the interstitial cells in the experimentally cryptorchid rat testis. Biol. Reprod. 20, 409-422.
Llaurado, J.G. \& Dominiquez, O.V. (1963) Effect of cryptorchidism on testicular enzymes involved in androgen biosynthesis. Endocrinology 72, 292295.

Rager, K., Zarzychi, J., Eichner, M. \& Gupta, D. (1975) Effects of experimental bilateral cryptorchidism and castration on the plasma gonadotropins in male rats during sexual maturation. Res. exp. Med. 165, 5559.

Schanbacher, B.D. (1976) Rapid chromatography for quantitation of radioimmunoassayable $5 \alpha$ androstane-17 $\beta$-ol-3-one and testosterone in ram, bull and boar serum. Endocr. Res. Commun. 3, 7182.

Schanbacher, B.D. (1978) Gonadotrophin secretion and testis function in artificially cryptorchid bulls. Theriogenology 10, 231-239. 
Schanbacher, B.D. (1979) Testosterone secretion in cryptorchid and intact bulls injected with gonadotropin-releasing hormone and luteinizing hormone. Endocrinology 104, 360-364.

Schanbacher, B.D. (1980) Androgen secretion and characteristics of testicular hCG binding in cryptorchid rats. J. Reprod. Fert. 59, 145-150.

Schanbacher, B.D. \& Ford, JJ. (1976) Luteinizing hormone, testosterone, growth and carcass responses to sexual alteration in the ram. J. Anim. Sci. 43, 638643.
Schanbacher, B.D. \& Ford, J.J. (1977) Gonadotropin secretion in cryptorchid and castrate rams and the acute effects of exogenous steroid treatment. Endocrinology 100, 387-393.

Sharpe, R.M., Kerr, J.B. \& de Kretser, D.M. (1978) Studies on Leydig cell function in cryptorchid rats. Endocrinology 102 (Suppl.), 372, Abstr. 594.

Swerdloff, R.S., Walsh, P.C., Jacobs, H.S. \& Odell, W.D. (1971) Serum LH and FSH during sexual maturation in the male rat: effect of castration and cryptorchidism. Endocrinology 88, 120-128.

Received 10 October 1979 